The Bracero Program 
THIS PAGE INTENTIONALLY LEFT BLANK 


\section{THE BRACERO PROGRAM Interest Groups and Foreign Policy}

by RICHARD B. CRAIG

UNIVERSITY O F TEXAS PRESS 
Copyright (C I97 I by Richard B. Craig

First paperback printing $20 \mathrm{I} 4$

All rights reserved

Printed in the United States of America

Requests for permission to reproduce material from this work should be sent to:

Permissions

University of Texas Press

P.O. Box 7819

Austin, TX 78713-78I9

http://utpress.utexas.edu/index.php/rp-form

Library of Congress Catalog Number 74-I659I4

ISBN 978-I-4773-0584-3, paperback

ISBN 978-I-4773-0585-0, library e-book

ISBN 978-I-4773-0586-7, individual e-book 
T O TH E O L E M A N

Would that he had lived to see his son become a starter 
THIS PAGE INTENTIONALLY LEFT BLANK 